\title{
Rice Husk Reuse in the Preparation of $\mathrm{SnO}_{2} / \mathrm{SiO}_{2}$ Nanocomposite
}

\author{
Carlos Sérgio Ferreira ${ }^{a}$, Pãmyla Layene Santos ${ }^{b}$, Juliano Alves Bonacin ${ }^{b}$, Raimundo Ribeiro Passos ${ }^{a}$, \\ Leandro Aparecido Pocrifka*
}

\author{
${ }^{a}$ GEMATA - LEEN, Departamento de Química, Universidade Federal do Amazonas - UFAM, \\ CEP 69077-000, Manaus, AM, Brazil \\ ${ }^{b}$ Molecular Nanotechnology Laboratory - LNANOMOL, Instituto de Quimica, Universidade \\ Estadual de Campinas - UNICAMP, CP 6154, CEP 13083-970, Campinas, SP, Brazil
}

Received: April 22, 2015; Revised: June 9, 2015

\begin{abstract}
In this study, biogenic $\mathrm{SiO}_{2}$ of high purity and high surface area obtained from rice husk was used for prepare a nanostructured $\mathrm{SnO}_{2} / \mathrm{SiO}_{2}$ composite. The predominantly amorphous silica was extracted in an acidic route and then the nanocomposite was done via sol-gel route using ethylene glycol and citric acid followed by heat treatment. $\mathrm{SiO}_{2}$ content of the rice husk was determined by X-ray fluorescence (XRF) and its specific surface area determined by nitrogen adsorption. The composite nanostructured $\mathrm{SnO}_{2} / \mathrm{SiO}_{2}$ was structurally characterized by the techniques of X-ray diffraction (XRD), Raman and Fourier transform infrared (FT-IR) spectroscopy. The morphological characteristics were revealed by scanning electron microscope (SEM).
\end{abstract}

Keywords: biogenic $\mathrm{SiO}_{2}$, rice husk, $\mathrm{SnO}_{2} \mathrm{SiO}_{2}$ composite, Pechini method

\section{Introduction}

Agroindustry has generated a large content of residues and a necessity of utilization of these residues might reduce pollution and increase energy savings. Among these residues, rice husks have received attention due to its large volume produced and high content of amorphous silica, approximately $21 \%{ }^{1,2} . \mathrm{SiO}_{2}$ can be obtained by direct calcination followed by calcination chemical treatment, and by sol-gel route. Silica from rice husk is considered as an alternative to commercial silica ${ }^{3}$ due to low cost and wide application, such as to obtain silicon carbide ${ }^{4}$, catalysts ${ }^{5}$, adsorbents ${ }^{6}$, zeolites $^{7}$, silicates ${ }^{8}$ and cement ${ }^{9}$.

Compared to conventional materials, nanomaterials have interesting physical and chemical properties, besides several areas of application, and relative easy production carried out by different methods such as microemulsion ${ }^{10}$, hydrothermal $^{11}$ and sol-gel ${ }^{12}$.

Tin oxide $\left(\mathrm{SnO}_{2}\right)$ is an important semiconductor oxide in the industry ${ }^{13}$, but despite its wide usage ${ }^{14-17}$ has low thermal stability and tendency to aggregation ${ }^{18}$, that can be overcome by incorporating the amorphous $\mathrm{SiO}_{2}$ to $\mathrm{SnO}_{2}^{[19]}$, generating the $\mathrm{SnO}_{2} / \mathrm{SiO}_{2}$ nanocomposite. There are several studies using $\mathrm{SnO}_{2} / \mathrm{SiO}_{2}$, like composite ${ }^{20}$, xerogel ${ }^{21}$, nanotubes ${ }^{22}$ and films ${ }^{23}$, which application can be in photocatalysis ${ }^{24}$ and sensors ${ }^{25}$.

This work aims prepare and characterize $\mathrm{SnO}_{2} / \mathrm{SiO}_{2}$ nanocomposites from amorphous biogenic silica of high purity extracted from rice husk by Pechini method ${ }^{26}$, as an alternative to TEOS (tetraethoxysilane). Silica from rice husk was characterized by X-ray fluorescence (XRF) and by physical adsorption of nitrogen. The $\mathrm{SnO}_{2} / \mathrm{SiO}_{2}$ nanocomposite was characterized by scanning electron microscopy (SEM), by

*e-mail: pocrifka@gmail.com
X-ray diffractometry (XRD) and Raman spectroscopy and Fourier transform infrared spectroscopy (FT-IR).

\section{Experimental}

\subsection{Extraction of $\mathrm{SiO}_{2}$ and Preparations of nanocomposite}

Extraction of silica was made by grinding of the rice husk (RH) followed by chemical treatment with $\mathrm{HCl}(10 \% \mathrm{v} / \mathrm{v})$, in the ratio $\mathrm{RH}: \mathrm{HCl} 1: 3$, for one hour with constant stirring to solubilize organic matter. The solubilized RH was washed with ultrapure water and it was filtered under vacuum, obtaining a pulp (PRH) which was treated with a solution of $\mathrm{H}_{2} \mathrm{SO}_{4}$ and $\mathrm{H}_{2} \mathrm{O}_{2}$ in the ratio of 1:2:1 (w/v/v) - $\mathrm{PRH}: \mathrm{H}_{2} \mathrm{SO}_{4}: \mathrm{H}_{2} \mathrm{O}_{2}$ under constant stirring for one hour to promote the oxidation of organic matter. Finally, the oxidized PRH was washed with ultrapure water and the biogenic $\mathrm{SiO}_{2}$ was obtained by vacuum filtering and calcinations in an oven for $4 \mathrm{~h}$ at $600^{\circ} \mathrm{C}$.

$\mathrm{SnO}_{2} / \mathrm{SiO}_{2}$ nanocomposite was prepared by adding biogenic silica and $\mathrm{SnCl}_{2} \cdot 2 \mathrm{H}_{2} \mathrm{O}$ to a solution of nitric acid (NA)/ethylene glycol (EG), obeying the following proportions 1:3:12 $\left(\mathrm{SnCl}_{2} \cdot 2 \mathrm{H}_{2} \mathrm{O}: \mathrm{CA}: \mathrm{EG}\right)$ and 1:4 (w/w) - $\left(\mathrm{SiO}_{2}: \mathrm{SnCl}_{2} \cdot 2 \mathrm{H}_{2} \mathrm{O}\right)$. This mixture was stirred for $1 \mathrm{~h}$ at $60^{\circ} \mathrm{C}$ with subsequent heat treatment at $250^{\circ} \mathrm{C}$ for 2 hours, followed by calcination at $400{ }^{\circ} \mathrm{C}$ during 1 hour. All steps of calcination and heat treatment were performed without heating rate.

\subsection{Characterization}

Biogenic silica was characterized by $\mathrm{x}$-ray fluorescence (XRF) using an Epsilon 3XL spectrometer. Specific surface area was determined by nitrogen gas adsorption using a 
Quantachrome Autosorb-iQ equipment by multipoint BET method (Brunauer Emmett Tell) and the average diameter of the silica particles was estimated using the following equation for spherical particles

$$
d_{B E T}=\frac{6}{\left(A_{B E T} \cdot \rho_{T E O}\right)}
$$

where $\rho_{T E O}$ is the theoretical density ${ }^{27}$ for the amorphous silica, having a value of $1,92 \mathrm{~g} \mathrm{~cm}^{-3}$ and $A_{B E T}$ is the specific surface area.

Morphology of $\mathrm{SnO}_{2} / \mathrm{SiO}_{2}$ nanocomposite was determined by scanning electron microscopy (SEM) using a JEOL model JMS6360-Lv microscope. The crystallinity of the material were characterized by X-ray diffraction (Shimadzu/ XRD-7000) with $\mathrm{CuK} \alpha$ radiation $(\lambda=1.542 \AA), 40 \mathrm{kV}$ and $30 \mathrm{~mA}$. Vibrational spectra were recorded on a Bomem MB-series spectrophotometer (Model B100) and Raman spectra were obtained using Confocal Raman equipment model T64000 Jobin-Yvon with laser excitation at $532 \mathrm{~nm}$. Composition of the biogenic silica and the nanocomposite were identified by XRF, and the crystallite size was determined by Debye-Scherrer equation:

$d=\frac{K \lambda}{\beta \cos \theta}$

where $d$ is crystallite size, $K$ is shape factor (typical value of about 0.89 for spherical crystalline solids with cubic unit cells), $\lambda$ is $\mathrm{CuX}$-ray wavelength (1.542 $\AA$ ), $\theta$ is Bragg diffraction angle and $\beta$ is the peak width of the diffraction peak profile at half maximum height.

\section{Results and Discussion}

\subsection{Amorphous $\mathrm{SiO}_{2}$}

Composition of the biogenic silica is shown in Table 1. According to the percentage values of the components, the methodology used to extraction provided $\mathrm{SiO}_{2}$ with purity of approximately $98.6 \%$, higher than commercial $\mathrm{SiO}_{2}{ }^{[28]}$. The analysis of the surface area by BET method showed an approximated ${ }^{29,30}$ value of $450 \mathrm{~m}^{2} \mathrm{~g}^{-1}$ and a mean particle size of $7 \mathrm{~nm}$, given by Equation 1 .

\subsection{Structural study of $\mathrm{SiO}_{2}$ and nanocomposite}

XRD diffractogram of the biogenic $\mathrm{SiO}_{2}$ is presented in Figure 1a and shows a broad peak located approximately at $2 \theta=22.5^{\circ}$, that suggests an amorphous characteristic of

Table 1. Composition of $\mathrm{SiO}_{2}$ determined by XRF.

\begin{tabular}{cr}
\hline Component & \multicolumn{1}{c}{$\%$} \\
\hline $\mathrm{SiO}_{2}$ & 98.589 \\
$\mathrm{P}_{2} \mathrm{O}_{5}$ & 0.834 \\
$\mathrm{Al}_{2} \mathrm{O}_{3}$ & 0.390 \\
$\mathrm{CaO}$ & 0.130 \\
$\mathrm{Fe}_{2} \mathrm{O}_{3}$ & 0.020 \\
$\mathrm{Ag}_{2} \mathrm{O}$ & 0.011 \\
$\mathrm{MnO}$ & 0.007 \\
$\mathrm{TiO}_{2}$ & 0.003 \\
$\mathrm{Cl}$ & 0.016 \\
\hline
\end{tabular}

the sample and agrees with the reported JCPDS data (card No. 01-086-1561).

XRD pattern for the nanocomposite is shown in Figure $1 \mathrm{~b}$ and reveals a small shoulder at $2 \theta=21.7^{\circ}$ that can be attributed to amorphous $\mathrm{SiO}_{2}$ and other peaks assigned to crystalline $\mathrm{SnO}_{2}$. All values of diffraction peaks are in accordance with JCPDS pattern (card No. 00-041-1485). The main diffraction peaks observed for $\mathrm{SnO}_{2}$ are centered approximately at $2 \theta$ values of $27.1^{\circ}, 34.2^{\circ}$ and $52.1^{\circ}$. In addition, the crystallite size based on the major diffraction peak is $27.8 \mathrm{~nm}$ for the nanocomposite.

\subsection{Morphology of nanocomposite}

Surface morphology of the nanocomposite is presented in Figure 2. SEM micrographs reveal formation of a heterogeneous mixture of agglomerates with irregular shapes and sizes.

\subsection{FTIR and Raman analyses}

FT-IR and Raman spectra for the $\mathrm{SnO}_{2} / \mathrm{SiO}_{2}$ nanocomposite are shown in Figure $3 \mathrm{a}$ and $3 \mathrm{~b}$, respectively. Comparisons between wavenumber obtained in this work with literature values are exhibited in Tables 2 and 3.

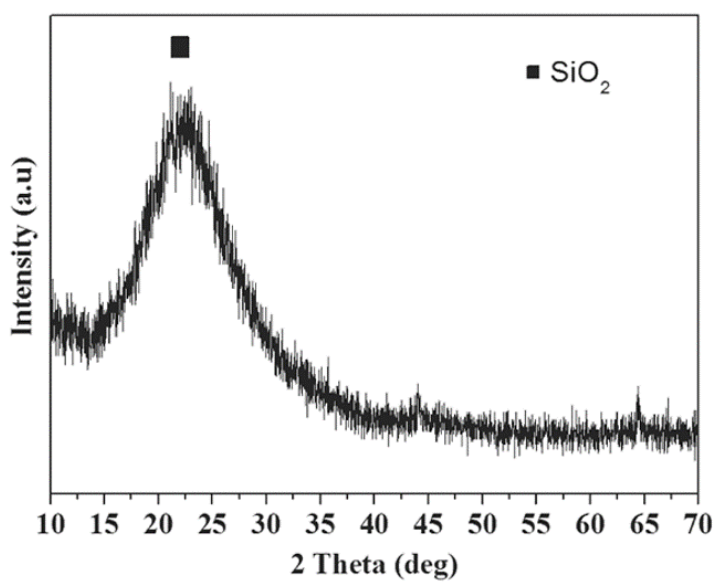

(a)

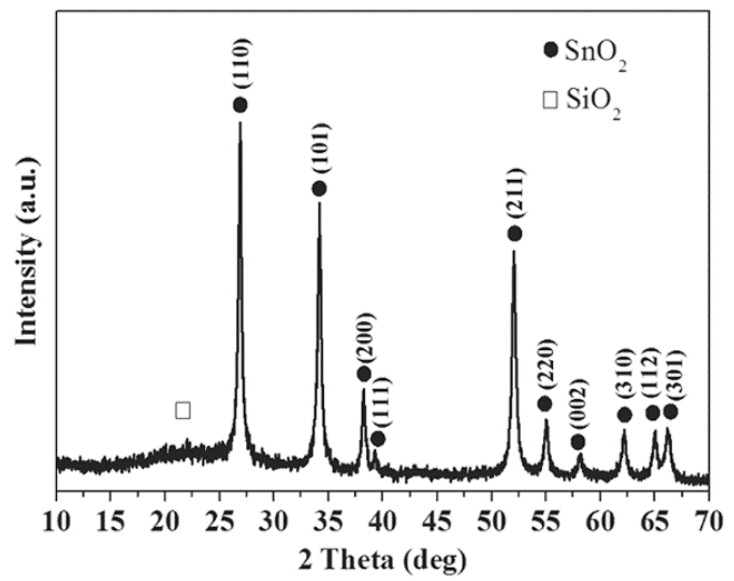

(b)

Figure 1. XRD obtained for (a) biogenic $\mathrm{SiO}_{2}$ from rice husk and (b) $\mathrm{SnO}_{2} / \mathrm{SiO}_{2}$ nanocomposite. 


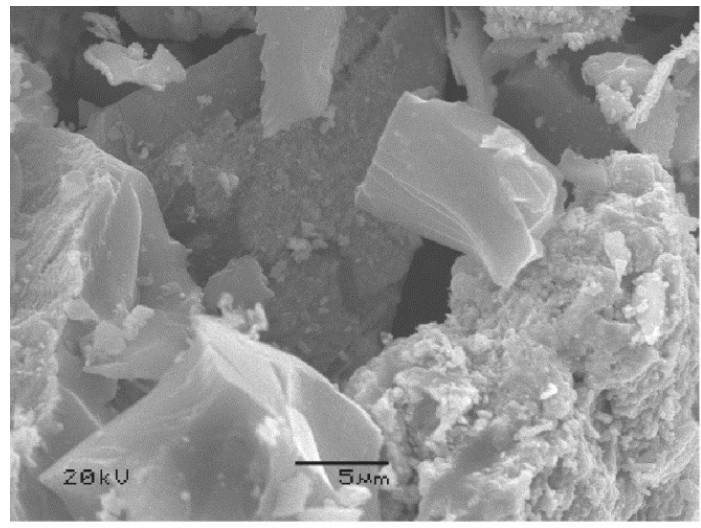

(a)

Figure 2. SEM images magnified (a) 3500 and (b) 10000 times.

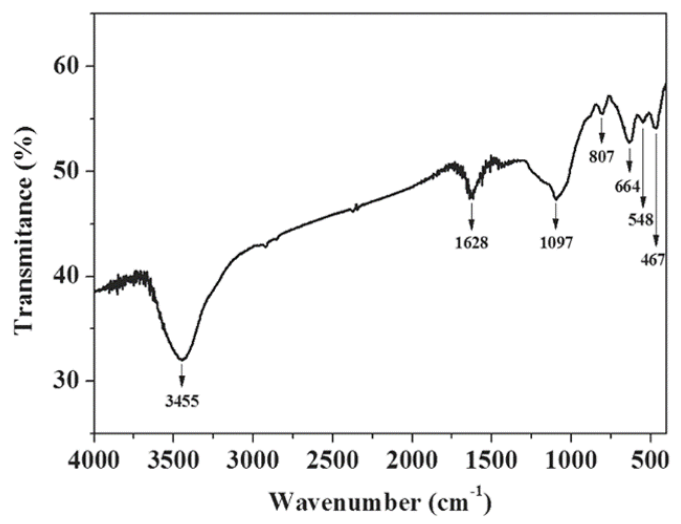

(a)

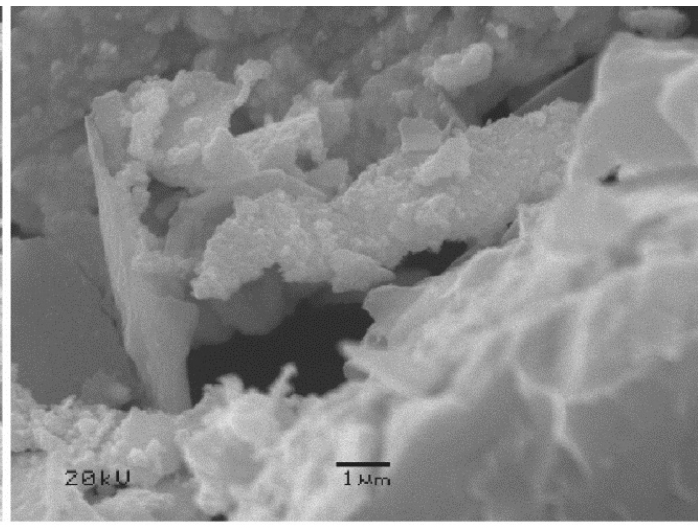

(b)

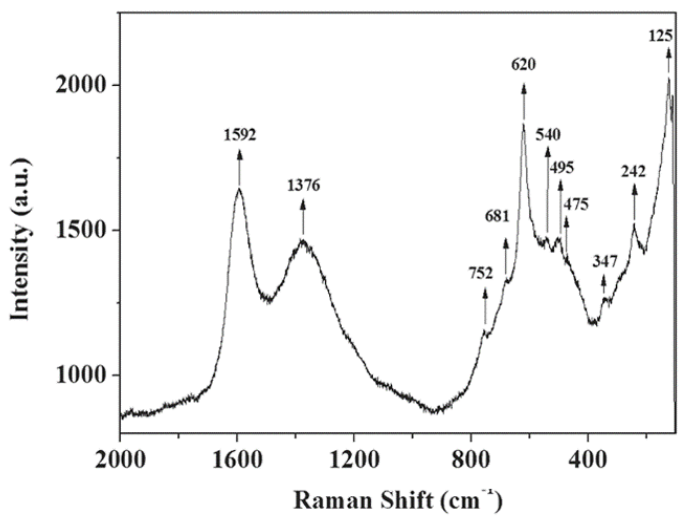

(b)

Figure 3. Spectra for the $\mathrm{SnO}_{2} / \mathrm{SiO}_{2}$ nanocomposite (a) FT-IR (b) Raman.

Table 2. Assignments of infrared bands of the $\mathrm{SnO}_{2} / \mathrm{SiO}_{2}$ nanocomposite.

\begin{tabular}{ccc}
\hline This work & Literature $^{\text {Ref }}$ & \\
\cline { 1 - 2 }$\left(\mathbf{c m}^{-1}\right)$ & $\left.\mathbf{( c m}^{-1}\right)$ & Assignment \\
\cline { 1 - 2 } 467 & $460^{30}$ & $\delta(\mathrm{Si}-\mathrm{O})$ \\
548 & $558^{32}$ & $v_{\text {sim }}(\mathrm{Sn}-\mathrm{O})$ \\
664 & $674^{32}$ & $v_{\text {ass }}(\mathrm{Sn}-\mathrm{O}-\mathrm{Sn})$ \\
807 & $800^{30}$ & $v_{\text {sim }}(\mathrm{Si}-\mathrm{O}-\mathrm{Si})$ \\
1097 & $1074^{30}$ & $v_{\text {ass }}(\mathrm{Si}-\mathrm{O}-\mathrm{Si})$ \\
1628 & $1620-1630^{29}$ & $\delta(\mathrm{H}-\mathrm{O}-\mathrm{H})$ \\
3455 & $3350-3450^{29}$ & $v(\mathrm{O}-\mathrm{H})$ \\
\hline
\end{tabular}

Infrared spectrum shows a broad band at $3455 \mathrm{~cm}^{-1}$ attributed to $\mathrm{O}-\mathrm{H}$ stretching from hydroxyl groups presents on surface of the material and the band at $1628 \mathrm{~cm}^{-1}$ is associated with bending $\mathrm{H}-\mathrm{O}-\mathrm{H}$ bond groups of adsorbed water molecules ${ }^{31}$. Bands at 467, 807 and $1097 \mathrm{~cm}^{-1}$ are assigned respectively to vibrational modes of O-Si-O bending, to symmetric stretching of Si-O-Si group and to the asymmetric stretching of Si-O-Si structural bond of siloxane $^{32}$. Vibrations in the range from 500 to $700 \mathrm{~cm}^{-1}$ are assigned to $\mathrm{Sn}-\mathrm{O}-\mathrm{Sn}$ group as result of condensation reactions ${ }^{33}$. The bands characterized by the peaks 548 and $664 \mathrm{~cm}^{-1}$ are assigned to the Sn-O stretching vibration and $\mathrm{Sn}-\mathrm{O}-\mathrm{Sn}$ asymmetric vibration, respectively ${ }^{34}$.
Table 3. Assignments of the Raman bands for the $\mathrm{SnO}_{2} / \mathrm{SiO}_{2}$ nanocomposite.

\begin{tabular}{ccc}
\hline This work & Literature & \\
\cline { 1 - 2 }$\left(\mathbf{c m}^{\mathbf{R}}\right)$ & $\mathbf{( c m}^{\mathbf{1}} \mathbf{)}$ & Assignment \\
\hline 1592 & $1580^{40}$ & $\mathrm{G}$ band \\
1376 & $1360^{40}$ & $\mathrm{D}$ band \\
752 & $774^{34}, 775^{35}$ & $\mathrm{~B}_{2 \mathrm{~g}}$ \\
681 & $687^{34}$ & $\mathrm{~A}_{2 \mathrm{u}} \mathrm{LO}$ \\
620 & $638^{34}, 631^{35}$ & $\mathrm{~A}_{1 \mathrm{~g}}$ \\
540 & $512^{34}$ & $\mathrm{~A}_{2 \mathrm{u}} \mathrm{TO}^{\dagger}$ \\
495 & $475^{34}, 474^{35}$ & $\mathrm{E}_{\mathrm{g}}$ \\
347 & $377^{34}$ & $\mathrm{E}_{\mathrm{u}}(2) \mathrm{LO}$ \\
242 & $236^{34}$ & $\mathrm{E}_{\mathrm{u}}(1) \mathrm{TO}$ \\
125 & $100^{34}$ & $\mathrm{~B}_{1 \mathrm{~g}}$ \\
\hline
\end{tabular}

${ }^{*} \mathrm{LO}$ - longitudinal optical phonons. ${ }^{\dagger} \mathrm{TO}$ - transverse optical phonons.

$\mathrm{SnO}_{2}$ has a tetragonal rutile crystalline structure with point group $\mathrm{D}_{4 \mathrm{~h}}{ }^{[35] \text {. }}$ ccording to Li et al. there are three typical modes to $\mathrm{SnO}_{2}$ in Raman spectrum $\left(474 \mathrm{~cm}^{-1}(\mathrm{Eg}), 631 \mathrm{~cm}^{-1}\right.$ $\left(\mathrm{A}_{1 \mathrm{~g}}\right)$ and $775 \mathrm{~cm}^{-1}\left(\mathrm{~B}_{2 \mathrm{~g}}\right)$. When the particle size decreases, $\mathrm{A}_{1 \mathrm{~g}}$ and $\mathrm{B}_{2 \mathrm{~g}}$ modes of $\mathrm{SnO}_{2}$ are shifted to lower wavenumbers and $\mathrm{E}_{\mathrm{g}}$ mode is shifted to higher wavenumber ${ }^{36}$. Obtained results have shown that mode at $475 \mathrm{~cm}^{-1}$ is assigned to translational mode $\left(\mathrm{E}_{\mathrm{g}}\right)$ of the oxide. On the other hand, mode 
at $620 \mathrm{~cm}^{-1}$ is assigned to symmetric $\mathrm{O}-\mathrm{Sn}-\mathrm{O}$ stretching $\left(\mathrm{A}_{1 \mathrm{~g}}\right)$ and the third mode at $752 \mathrm{~cm}^{-1}$ is assigned to asymmetric O-Sn-O stretching $\left(\mathrm{B}_{2 \mathrm{~g}}\right)^{37}$.

The position of $\mathrm{SnO}_{2}$ peak in Raman spectrum is dependent of particle size and a fourth vibrational mode $\left(\mathrm{B}_{1 \mathrm{~g}}\right)$ peak appears only to nanomaterials. Thus, in the Raman spectrum the presence of an intense peak centered at $125 \mathrm{~cm}^{-1}$ is associated to non degenerated $\mathrm{B}_{1 \mathrm{~g}}$ mode of $\mathrm{SnO}_{2}$ and is assigned to rotation of the oxygen atoms, with all oxygen atoms participating in the vibration at tetragonal unit cell of rutile $^{36}$. All modes and assignments are presented in Table 3 .

The effects of particle size and disorder in the material lead to a relaxation of the Raman selection rule, and some modes that are usually inactive in Raman become actives. Furthermore, the peaks at $242 \mathrm{~cm}^{-1}, 347 \mathrm{~cm}^{-1}, 540 \mathrm{~cm}^{-1}$ and $681 \mathrm{~cm}^{-1}$ were assigned to optical phonon modes of $\mathrm{SnO}_{2}$, $\mathrm{E}_{\mathrm{u}}(1) \mathrm{TO}, \mathrm{E}_{\mathrm{u}}$ (2) LO, $\mathrm{A}_{2 u} \mathrm{TO}$ and $\mathrm{A}_{2 u} \mathrm{LO}$ of $\mathrm{SnO}_{2}$, where LO and TO are longitudinal and transverse optical phonons, respectively ${ }^{34,38-40}$.

Peaks at 1354 and $1587 \mathrm{~cm}^{-1}$ are termed D and G bands, respectively ${ }^{41}$, and confirm the presence of amorphous carbon

\section{References}

1. Umeda J, Kondoh K and Michiura Y. Process parameters optimization in preparing high-purity amorphous silica originated from rice husks. Materials Transactions. 2007; 48(12):30953100. http://dx.doi.org/10.2320/matertrans.MK200715.

2. Shen J, Liu X, Zhu S, Zhang H and Tan J. Effects of calcination parameters on the silica phase of original and leached rice husk ash. Materials Letters. 2011; 65(8):1179-1183. http://dx.doi. org/10.1016/j.matlet.2011.01.034.

3. Adam F, Appaturi JN, Khanam Z, Thankappan R and Nawi MAM. Utilization of tin and titanium incorporated rice husk silica nanocomposite as photocatalyst and adsorbent for the removal of methylene blue in aqueous medium. Applied Surface Science. 2013; 264:718-726. http://dx.doi.org/10.1016/j. apsusc.2012.10.106.

4. Gorthy P and Pudukottah M. Production of silicon carbide from rice husks. Journal of the American Ceramic Society. 1999; 82(6):1393-1400. http://dx.doi.org/10.1111/j.1151-2916.1999. tb01929.x.

5. Adam F, Appaturi JN and Iqbal A. The utilization of rice husk silica as a catalyst: review and recent progress. Catalysis Today. 2012; 190(1):2-14. http://dx.doi.org/10.1016/j.cattod.2012.04.056.

6. Adam $\mathrm{F}$ and Chua JH. The adsorption of palmytic acid on rice husk ash chemically modified with $\mathrm{Al}$ (III) ion using the sol-gel technique. Journal of Colloid and Interface Science. 2004; 280(1):55-61. http://dx.doi.org/10.1016/j.jcis.2004.07.006. PMid: 15476773 .

7. Gaydhankar TR, Joshi PN, Kalita P and Kumar R. Optimal synthesis parameters and application of Sn-MCM-41 as an efficient heterogeneous catalyst in solvent-free Mukaiyamatype aldol condensation. Journal of Molecular Catalysis A Chemical. 2007; 265(1-2):306-315. http://dx.doi.org/10.1016/j. molcata.2006.10.041.

8. Naskar MK and Chatterjee M. A novel process for the synthesis of lithium aluminum silicate powders from rice husk ash and other water-based precursor materials. Materials Letters. 2005; 59(8-9):998-1003. http://dx.doi.org/10.1016/j.matlet.2004.06.075.

9. Ganesan K, Rajagopal K and Thangavel K. Rice husk ash blended cement: Assessment of optimal level of replacement for that is typical of the temperature and of the sol-gel route used for obtain the nanocomposite.

\section{Conclusion}

Biogenic $\mathrm{SiO}_{2}$ extracted from rice husk and the $\mathrm{SnO}_{2} / \mathrm{SiO}_{2}$ nanocomposite were characterized by XRF, XRD, SEM, FTIR and Raman. The method used in $\mathrm{SiO}_{2}$ extraction was efficient to obtain amorphous biogenic $\mathrm{SiO}_{2}$ of high purity in nanometer scale. $\mathrm{SnO}_{2} / \mathrm{SiO}_{2}$ nanocomposite behaved as a solid mixture of $\mathrm{SiO}_{2}$ of low crystallinity and crystalline $\mathrm{SnO}_{2}$. Therefore, from rice rusk is possible obtain biogenic $\mathrm{SiO}_{2}$ of high purity that added to $\mathrm{SnO}_{2}$ provide the $\mathrm{SnO}_{2} / \mathrm{SiO}_{2}$ nanocomposite.

\section{Acknowledgements}

The authors acknowledge financial assistance from FAPEAM (Grant \# 2985/2012) and the Laboratory of Advanced Optical Spectroscopy (LMEOA/IQ-UNICAMP/ FAPESP Grant \# 2009/54066-7) for use of Raman equipment.

strength and permeability properties of concrete. Construction \& Building Materials. 2008; 22(8):1675-1683. http://dx.doi. org/10.1016/j.conbuildmat.2007.06.011.

10. Lakshmanan R, Okoli C, Boutonnet M, Jaras S and Rajarao GK. Microemulsion prepared magnetic nanoparticles for phosphate removal: Time efficient studies. Journal of Environmental Chemical Engineering. 2014; 2(1):185-189. http://dx.doi. org/10.1016/j.jece.2013.12.008.

11. Yang W, Gao Z, Wang J, Wang B and Liu L. Hydrothermal synthesis of reduced graphene sheets/ $\mathrm{Fe} 2 \mathrm{O} 3$ nanorods composites and their enhanced electrochemical performance for supercapacitors. Solid State Sciences. 2013; 20:46-53. http:// dx.doi.org/10.1016/j.solidstatesciences.2013.03.011.

12. Ebrahimi A, Pirouz A, Abdi Y, Azimi S and Mohajerzadeh S. Selective deposition of $\mathrm{CuO} / \mathrm{SnO} 2$ sol-gel on porous $\mathrm{SiO} 2$ suitable for the fabrication of MEMS-based H2S sensors. Sensors and Actuators. B, Chemical. 2012; 173:802-810. http:// dx.doi.org/10.1016/j.snb.2012.07.104.

13. Manjula P, Satyanarayana L, Swarnalatha Y and Manorama SV. Raman and MASNMR studies to support the mechanism of low temperature hydrogen sensing by Pd doped mesoporous SnO2. Sensors and Actuators. B, Chemical. 2009; 138(1):28-34. http://dx.doi.org/10.1016/j.snb.2009.02.051.

14. Zhao Y, Liu J, Liu Q, Sun Y, Song D, Yang W, et al. One-step synthesis of $\mathrm{SnO} 2$ hollow microspheres and its gas sensing properties. Materials Letters. 2014; 136:286-288. http://dx.doi. org/10.1016/j.matlet.2014.08.073.

15. Wang F, Song X, Yao G, Zhao M, Liu R, Xu M, et al. Carboncoated mesoporous $\mathrm{SnO} 2$ nanospheres as anode material for lithium ion batteries. Scripta Materialia. 2012; 66(8):562-565. http://dx.doi.org/10.1016/j.scriptamat.2012.01.003.

16. Shimizu K, Katagiri M, Satokawa S and Satsuma A. Sinteringresistant and self-regenerative properties of $\mathrm{Ag} / \mathrm{SnO} 2$ catalyst for soot oxidation. Applied Catalysis B: Environmental. 2011; 108-109:39-46. http://dx.doi.org/10.1016/j.apcatb.2011.08.003.

17. Dou X, Sabba D, Mathews N, Wong LH, Lam YM and Mhaisalkar S. Hydrothermal Synthesis of High Electron Mobility Zn-doped SnO 2 Nanoflowers as Photoanode Material for Efficient Dye-Sensitized Solar Cells. Chemistry of Materials. 2011; 23(17):3938-3945. http://dx.doi.org/10.1021/cm201366z. 
18. Feng YS, Zhou SM, Li Y and Zhang LD. Preparation of the $\mathrm{SnO} 2 / \mathrm{SiO} 2$ xerogel with a large specific surface area. Materials Letters. 2003; 57(16-17):2409-2412. http://dx.doi.org/10.1016/ S0167-577X(02)01245-4.

19. Granger G, Restoin C, Roy P, Jamier R, Rougier S, Lecomte A, et al. Nanostructured optical fibers in the $\mathrm{SiO} 2 / \mathrm{SnO} 2$ system by the sol-gel method. Materials Letters. 2014; 120:292-294. http://dx.doi.org/10.1016/j.matlet.2014.01.104.

20. An GH and Ahn HJ. Fabrication of $\mathrm{SnO} 2$ and $\mathrm{SiO} 2$ nanoparticleembedded carbon nanofiber composites via co-electrospinning. Ceramics International. 2012; 38(4):3197-3201. http://dx.doi. org/10.1016/j.ceramint.2011.12.024.

21. Grieken RV, Martos C, Sánchez MS, Serrano DP, Melero JA, Iglesias J, et al. Synthesis of Sn-silicalite from hydrothermal conversion of SiO2-SnO2 xerogels. Microporous and Mesoporous Materials. 2009; 119:176-185.

22. Adam F, Appaturi JN, Thankappan R and Nawi MAM. Silicatin nanotubes prepared from rice husk ash by sol-gel method: Characterization and its photocatalytic activity. Applied Surface Science. 2010; 257(3):811-816. http://dx.doi.org/10.1016/j. apsusc.2010.07.070.

23. Lorenzi R, Lauria A, Mochenova N, Chiodini N and Paleari A. Study of the absorption edge of $\mathrm{SnO} 2$ nanoparticles embedded in silica films. Journal of Non-Crystalline Solids. 2011; 357(89):1888-1891. http://dx.doi.org/10.1016/j.jnoncrysol.2010.12.045.

24. Wei TY, Kuo CY, Hsu YJ, Lu SY and Chang YC. Tin oxide nanocrystals embedded in silica aerogel: Photoluminescence and photocatalysis. Microporous and Mesoporous Materials. 2008; 112(1-3):580-588. http://dx.doi.org/10.1016/j. micromeso.2007.10.040.

25. Zhu Y, Chen J, Li H, Zhu Y and Xu J. Synthesis of mesoporous $\mathrm{SnO} 2-\mathrm{SiO} 2$ composites and their application as quartz crystal microbalance humidity sensor. Sensors and Actuators. B, Chemical. 2014; 193:320-325. http://dx.doi.org/10.1016/j. snb.2013.11.091.

26. Pechini MP. Method of preparing lead and alkaline earth titanates and niobates and coating method using the same to form a capacitor. US 3330697. 1967 July 11.

27. Yalcà $N$ and Sevinç V. Studies on silica obtained from rice husk. Ceramics International. 2001; 27:219-224. http://dx.doi. org/10.1016/S0272-8842(00)00068-7.

28. Della VP, Hotza D, Junkes JA and Oliveira APN. Estudo comparativo entre sílica obtida por lixívia ácida da casca de arroz e sílica obtida por tratamento térmico da cinza de casca de arroz. Quimica Nova. 2006; 29(6):1175-1179. http://dx.doi. org/10.1590/S0100-40422006000600005.

29. Yu X, Tian J, Xie H, Shen H and Wang Q. The integrated production of microbial lipids and bio-SiO2 from rice husks by an organic electrolytes pretreatment technology. Bioresource Technology. 2014; 153:403-407. http://dx.doi.org/10.1016/j. biortech.2013.12.039. PMid:24398252.
30. Watari TI, Nakata A, Kiba Y, Torikai T and Yada M. Fabrication of porous $\mathrm{SiO} 2 / \mathrm{C}$ composite from rice husks. Journal of the European Ceramic Society. 2006; 26(4-5):797-801. http:// dx.doi.org/10.1016/j.jeurceramsoc.2005.06.013.

31. Yang S and Gao L. Facile and surfactant-free route to nanocrystalline mesoporous tin oxide. Journal of the American Ceramic Society. 2006; 89(5):1742-1744. http://dx.doi. org/10.1111/j.1551-2916.2006.00947.x.

32. Jung HY, Gupta RK, Oh EO, Kim YH and Whang CM. Vibrational spectroscopic studies of sol-gel derived physical and chemical bonded ORMOSILs. Journal of Non-Crystalline Solids. 2005; 351(5):372-379. http://dx.doi.org/10.1016/j. jnoncrysol.2005.01.004.

33. Li Z, Shen W, Zhang X, Fang L and Zu X. Controllable growth of $\mathrm{SnO} 2$ nanoparticles by citric acid assisted hydrothermal process. Colloids and Surfaces. A, Physicochemical and Engineering Aspects. 2008; 327(1-3):17-20. http://dx.doi.org/10.1016/j. colsurfa.2008.05.043.

34. Mohamed SH. SnO2 dendrites-nanowires for optoelectronic and gas sensing applications. Journal of Alloys and Compounds. 2012; 510(1):119-124. http://dx.doi.org/10.1016/j.jallcom.2011.09.006.

35. Katiyar RS, Dawson P, Hargreave MM and Wilkinson GR. Dynamics of the rutile structure. III. Lattice dynamics, infrared and Raman spectra of SnO 2. Journal of Physics. C. Solid State Physics. 1971; 4(15):2421-2431. http://dx.doi.org/10.1088/00223719/4/15/027.

36. Diéguez A, Rodríguez AR, Vilà A and Morante JR. The complete Raman spectrum of nanometric $\mathrm{SnO}$ [sub 2] particles. Journal of Applied Physics. 2001; 90(3):1550-1557. http://dx.doi. org/10.1063/1.1385573.

37. Li L. Growth and photoluminescence properties of $\mathrm{SnO} 2$ nanobelts. Materials Letters. 2013; 98:146-148. http://dx.doi. org/10.1016/j.matlet.2013.02.038.

38. Mendes PG, Moreira ML, Tebcherani SM, Orlandi MO, Andrés J, Li MS, et al. SnO2 nanocrystals synthesized by microwaveassisted hydrothermal method: towards a relationship between structural and optical properties. Journal of Nanoparticle Research. 2012; 14(3):750-762. http://dx.doi.org/10.1007/ s11051-012-0750-7.

39. Zhou JX, Zhang MS, Hong JM and Yin Z. Raman spectroscopic and photoluminescence study of single-crystalline $\mathrm{SnO} 2$ nanowires. Solid State Communications. 2006; 138(5):242-246. http://dx.doi.org/10.1016/j.ssc.2006.03.007.

40. Sun SH, Meng GW, Zhang GX, Gao T, Geng BY, Zhang LD, et al Raman scattering study of rutile $\mathrm{SnO} 2$ nanobelts synthesized by thermal evaporation of Sn powders. Chemical Physics Letters. 2003; 376(1-2):103-107. http://dx.doi.org/10.1016/ S0009-2614(03)00965-5.

41. Faria DLA and Lopes FN. Análise de pinturas rupestres do Abrigo do Janelão (Minas Gerais) por microscopia raman. Quimica Nova. . 2011; 34(8):1358-1364. http://dx.doi.org/10.1590/ S0100-40422011000800012. 